\title{
Effect of Two Bioformulation Trichoderma harzianum and Pseudomonas fluorescens with Manure in Controlling Fusarium wilt Disease in Pumpkin
}

\author{
Dhia S. Al-Waily \\ Sabreen M. Hassan \\ Basrah University, Agriculture College, Plant Protection Dept. \\ Kararkarar603@yahoo.com
}

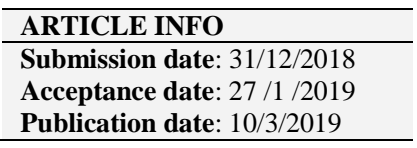

Abstract

This research aimed to isolate and identified the pathogen caused wilt in pumpkin plants and control by two bioformulation Trichoderma harzianum and Pseudomonas fluorescens.

The results revealed that the caused pathogen of pumpkin wilt plants was Fusarium oxysporum which diagnosis has been confirmed by using PCR Technique.

The results of pathogenesity revealed that $60.17 \%$ from Plants grown in contaminated soil infected with $F$. oxysporum. Also the results showed that use the $T$. harzianum that has high antagonism with pathogen, the degree of antagonism has reached 2 with $F$. oxysporum at Bell scale. $P$. fluorescens showed inhibition ratio against $F$. oxysporum and $T$. harzianum. reached 44 and $27 \%$ respectively. The results with use antibiosis for $T$. harzianum , P. fluroescens and manure revealed that the least severity was in the transactions MThPf (manure, fungi and Bacteria), MTh (manure and fungi), ThPf (fungi and bacteria), Th (T. harzianum), Pf (P. fluorescens), MPf (manure and bacteria), where ranged 0 - 5.56\%, which did not differ significantly between them compared to $\mathrm{M}$ (manure) and control that reached $13.69 \%$ and $22.22 \%$ respectively. Weight in soil contaminated with pathogen in MThPf and ThPf that reached 376.83 and 379.22gr compard with control in the same soil when reached $66.41 \mathrm{gr}$.The results of the analysis with used GCMas revealed transactions in presence of Antibiotics and substances Phenol 2,5-bis (1,1-dimethyl), 4-Fluorobenzyl alcohol, Hexadecanoic acid (2) -methyl ester, 1-Pyrrolidine butanoic acid, gamma-Tocophenol and 9-Octanoic acid (2) -2-hydrox.

Key words: pumpkin, Cucurbita pepo, Fusarium wilt, Fusarium oxysporum, biological control, Trichoderma spp., Pseudomonas fluorescens.

\section{Introduction}

Cucurbita pepo $\mathrm{L}$. is one of the most important summer vegetable crops desired in Iraq and is cultivated in all areas of Iraq in the open fields. Planted by two seasons , the first one is spring season begins in March to give production in late April and the second autumn season during August to give production in October (1).

Each $100 \mathrm{~g}$ of pumpkin fruits gave a low proportion of fat and carbohydrates reached $66 \%$, protein $3 \%$,High carotidene content $15 \%$, and fiber $11.46 \%$, ash $16 \%$ and 80 calories( 2 and 3 ).

The symptoms of infection by Fusarium oxysporum in plants, the plant is wilted gradually with the yellowing of the lower leaves, symptoms of wilt may suddenly appear on the plants in the warm atmosphere or the sunny notes also notice a clear change in color of stem or in the holding of the leaves and when working a longitudinal section in the stems showed the vessels are colored brown (4).

(5) proved that $P$. fluorescens bacteria are capable of inhibition of the growth of the $F$. oxysporum in media and its ability to stimulate systemic resistance and reduced 
disease severity in pathogenicity. As a result of the lack of studies on the plants of pumpkin Therefore, the study aimed at isolating and diagnosing the caused pathogen agent of pumpkin plants by PCR technique and then controlled by two bioformulations Trichoderma harzianum and Pseudomonas fluorescens.

\section{Material and Methods}

\section{Isolation and diagnosis of caused pathogen}

Random samples of the waxy plant pumpkin were brought to the lab from the Safwan and Zubair regions in the province of Basra, the infected plant parts (leaves) were washed with running water, cut by sterile scalpel $(1 \mathrm{~cm})$ and then sterilized with sodium hypochlorite solution $(\mathrm{NaOCl})$ at $1 \%$ concentration for one minute, It was then washed with distilled water to remove the traces of sodium hypochlorite solution and dried with filter paper type whatman1, and then planted in the petri dishes which had $9 \mathrm{~cm}$ diameter contain solid PDA media which added antibiotic Chloramphenicol (250mg. $\mathrm{l}^{-1}$ ) replicated with three dishes which had five pieces per dish, then incubate at $25 \pm 2{ }^{\circ} \mathrm{C}$ for 7 days (6).

\section{The diagnosis of pathogen by PCR Technique}

The used of PCR procedure in Sciences faculty for girls University.of Babylon by Prof.Dr.Ziedan AL-Maamory .

\section{The pathogenicity of $F$. oxysporum test:}

$F$. oxysporum was grow on millet grains and incubated at $25 \pm 2^{\circ} \mathrm{C}$ for 14 days , which was added to $(10 \mathrm{gr} / \mathrm{pot})$ the plastic pots $(6 \mathrm{~kg})$ which contained steriled soil and manure (1:3), which replicated with three pots in addition to the control treatment, The four-week-old pumpkin seedlings were picked up in corks.

The severity of infection was calculated after four weeks according to the following pathological severity scale:-

$\begin{array}{cl}\text { Degree } & \text { Infection } \\ 1 & \text { Light yellowing and wetness of the first two leaves } \\ 2 & \text { Yellowing and wetting a number of lower leaves } \\ 3 & \text { Extreme wilt and plant death }\end{array}$

An equation of Mickenny has been applied (6).

The fungi were then re-isolated from the plants that showed the infection.

\section{The inhabition of $F$. oxysporum and $T$. harzianum with $P$.fluorscens .}

The sterile medium KBA was infused in sterile plastic Petri dishes diameter of 9 $\mathrm{cm}$ and then the dishes were vaccinated with a bacterial KBA at 48 hours with four drops / dish of $0.1 \mathrm{ml} /$ drop , the sides of the diagonals are perpendicular and $1 \mathrm{~cm}$ from the edge of the dish and then incubated the dishes at $25{ }^{\circ} \mathrm{C}$ for a period 48 hours , Infected the center of each dish $0.5 \mathrm{~cm}$ diameter from the $T$. harzianum which growth in PDA medium by four days' by three replicates with control treatment and then incubated at $25 \pm 2^{\circ} \mathrm{C}$. The percentage of inhibition after growth in the control treatment was calculated to the edge of the dish according to the equation Aboutt 1935(6) . 
The effect of manure and bioformulation of $T$. harzianum and $P$. fluorescens in growth indicators.

After four-week the pumpkin plants were transferred to soil with organic fertilizer, biopharmaceuticals and pathogenic fungus in a field of $16 \mathrm{~m}$ long and $4 \mathrm{~m}$ wide in soil wich covered with plastic and added to the soil and installed hoses Doping was carried out and the treatments such as with biochemistry + bacteria + compost (MThPf) and biochemistry + manure (MTh), Bacterium + manure(MPf), manure (M), Biochemistry + Bacteria ThPf, Th, Pf, and Control. (1) were carried out . The same treatments were performed without the use of the pathogen, and the research soil was divided into two parts: the first was added to the fungus $F$. oxysporum by $10 \mathrm{~g} / \mathrm{m}$ long and the other part was left without the addition of pathogenic fungus Bioreactors were added $10 \mathrm{~g} / \mathrm{m}$ in length (6).

Determination of some compounds in some treatments using GC-mass technique.

In the flowering stage, a group of leaves was randomly taken for each treatment well washed with water to remove the dust and then distilled water and dried the leaves at $70^{\circ} \mathrm{C}$. for three days, crushed to fine powder using ceramic mortar and stored at $40^{\circ} \mathrm{C}$, It took $20 \mathrm{~g}$ of powdered hazelnut leaves for each treatment and placed in a kirin electric mixer and added $200 \mathrm{ml}$ ethyl alcohol at a concentration of $99.99 \%$ for 10 minutes, then put in mixture in a hotplate magnetic Stirrer for 48 hours at $50^{\circ} \mathrm{C}$, And then placed in the centrifuge at 3000 cycles / minute for 30 minutes, and neglected the deposit and take leachate and repeated and nominated using the paper filter No. whatman 1, which was placed in the oven at $40{ }^{\circ} \mathrm{C}(7)$, and then placed in sterile bottles, and samples were analyzed at the environmental research center in Baghdad department of environmental research and water affiliated to the ministry of science and technology.

\section{Result and Discussion}

Isolation and diagnosis of $F$. oxysporum and pathogenicity:

Isolation of $F$. oxysporum from the pumpkin plants which infected with Fusarium wilt disease. The morphological characteristics, spores form, pregnant carrier and non-natural structures by Assist. Prof. Dr. Dhia Salem Al - Waily according to the taxonomic keys contained in (8) and (9), It has been observed that colonies of fungi characterized by lumbar growth or sparse or abundant fungal yarn with the emergence of rings Surrounding the mushroom center, colonies of this mushroom appear pale orange and sometimes appear in violet or the pale purple from the back of the dish, In addition to the fungus, there are three types of spores, which are large conidic spores that are short to medium in length straight to the sickle shape and small conidial spores in large numbers It is characterized by its semi-oval shape, which originates on the phyllides and often has a basal foot cell, the spines are spherical and sometimes curved. These spores consist of a group of short-term assemblies and chlamydia spores that appear either in single cells or in short-term or interstitial chains ,That's agree with (8) and (9) . 


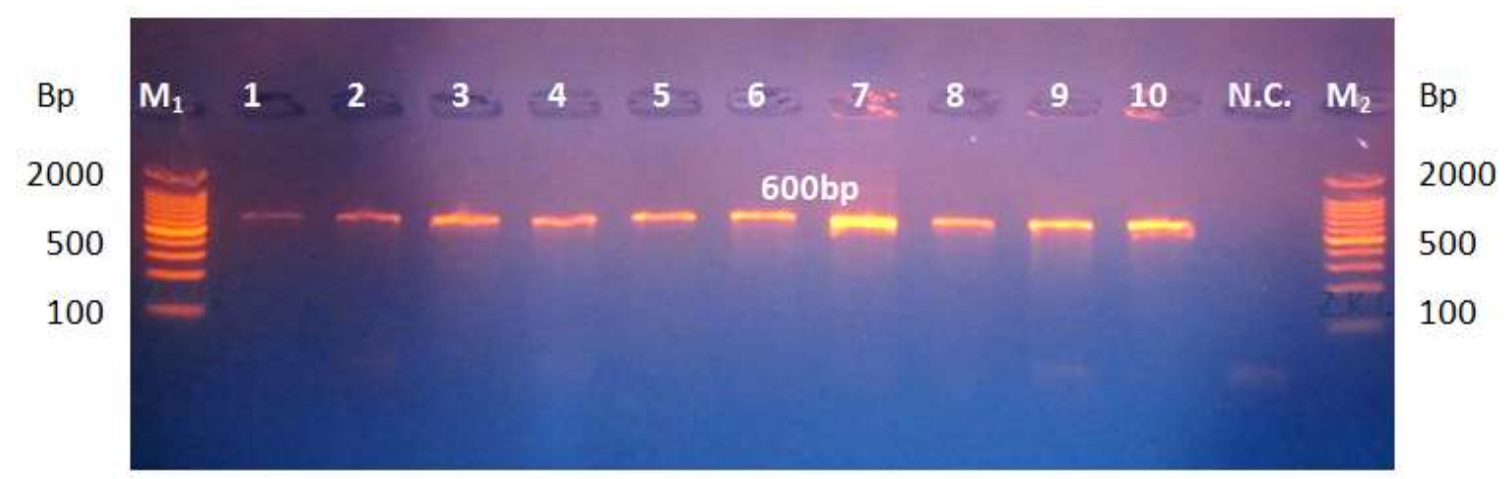

Fig.(1) Alkarose gel for polystyrene product for the ITS1-5.8S-ITS2 region using the PI5SIS / ITS4 primer pair of F.oxysporum isolates which isolated from the plant (10-1) which showed a hereditary pattern (BP 600) approximately N.C. Negative control. M1, M2 = Molecular parameter (2000bp) Each step = 100bp

The results(Fig.2) showed that the severity of $F$. oxysporum was $60.71 \%$ Compared to the comparison in which no injury occurred.

The symptoms of the infection appeared on the plant in a slight yellowing and the first two leaves wilt and then yellowing and the decline of a number of lower leaves and the progress of the fungus led to a severe wilt of the plant and the death of the entire plant .This may be due to the introduction of fungus into the plant tissue by penetrating the cellular walls due to susceptibility some isolates on the production of cellulose and decomposed enzymes for cell walls (10).

The pathogen fungi attack the root of the plant and grow in the interstitial spaces and eventually extend the innate spinning of the wooden veneer vessels and settle in. The vessel can be filled with fungal spores, small conidic bacteria or polysaccharides produced by fungi. The receptor of the vessel is increased from the products of the decomposition of plant cells by pathogenic fungus enzymes (11).

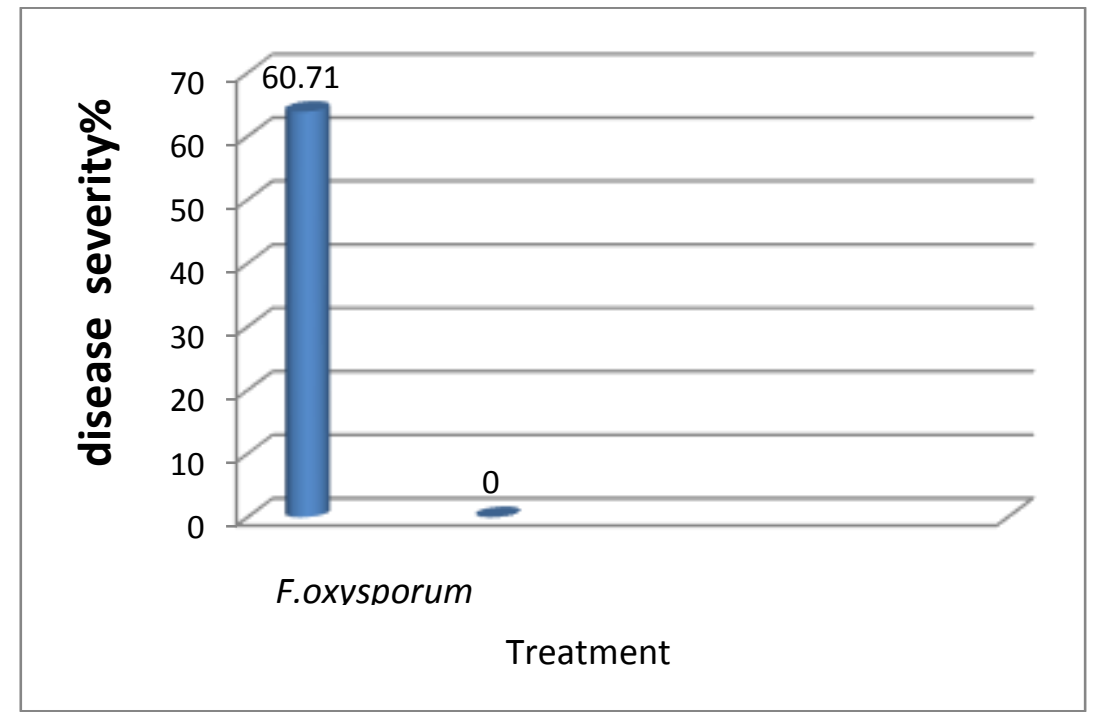

Fig.1.pathogenicity of F.oxysporm. 


\section{Antibiosis of $T$. harzianum. against $F$. oxysporum.}

Results (Table 1)suggest that T.harzianum has high antibacterial ability with $F$. oxysporum where it worked to discourage it on the media, where the average growth rate of the colony $2.04 \mathrm{~cm}$ compared to the growth of fungus on the media alone, which reached $8.5 \mathrm{~cm}$, as shown by the same table, the degree of antagonism was class 2 to inhibit pathogenic fungus, explaining the high efficiency of T.harzianum .

The path of the fungus on the basis of direct parasitism By spinning the yarn around the fungal threads of the nurse and grow on them , These agree with (12) he has been found that the mechanism used by the fungus resistance through microscopic observations in the dual farms( Double Culture) It includes the vital resistance fungus spinning snail (Coiling )around the pathogen and then the secretion of antibiotics and some enzymes to analyze the walls of fungus cells, such as Protease,$\beta-1-3$-glucanase 9Chitinase, This result confirms the findings of (13).they found the antibiotics and enzymes are found to assist in the analysis, feeding and feeding of host cells (Necrotrophic).This agree with (14) and (15), whom found that the fungus of biological resistance is used in several mechanisms, such as brooding on fungus, the secretion of antibiotics or competition for food and place.

Table1 : Antagonism between T. harzianum and fungi disease $F$. oxysporum.

\begin{tabular}{|l|c|c|}
\hline \multicolumn{1}{|c|}{ Treatment } & $\begin{array}{c}\text { Colony growth } \\
\text { rate }(\mathrm{cm})\end{array}$ & $\begin{array}{c}\text { Degree of } \\
\text { antagonism }\end{array}$ \\
\hline T.harzianum+F. oxysporum & ${ }^{\star} 2.04$ & 2 \\
\hline F.oxysporum & 8.5 & \\
\hline
\end{tabular}

mean three replicates*

Inhibition of F.oxysporum and T. harzianum by $P$. fluroscens.

The results as showed in Table (2) indicate that $P$. fluorescens was inhibit $T$. harzianum by reached at $27 \%$ in PDA mediuum , P. fluorescens reduced the growth of T.harzianum. P. fluorescens showed high inhibition efficiency of F.oxysporum by reached at $44 \%$ which caused inhibit of fungi growth on medium, and may be due to the inhibition of $P$. fluorescens for fungus to produces some antibiotics such as lipopeptid, amphisin and their production of some enzymes surrounding the fungal cell walls the enzyme such as endochitinase (6 and 16), this result agree with (17), he explained that $P$. fluorescens in the inhibition of the growth of F.oxysporum reached $100 \%$. (5) explanted the ability of $P$. fluorescens to inhibit the growth of F.oxysporum where the highest percentage of inhibition compared to other tested bacteria rached $52 \%$, , (18) also demonstrated that the thermodynamic Pseudomonas glumia bacteria showed effective resistance against $P$. solacearum in the center of the plant,may be the high resistance of $P$. fluorescens to the production of different types of antibiotics such as phenzain -1-caroxylate (19) or to the production of enzymes for fungal cell walls such as Chitinolytic enzyme and Catalase and the production of HCN (20).and enzyme chitinaseylytic, Protease and b-1.3-glucanase (21). 
Table 2: Effect of $P$. fluorescens in F.oxysporum and T.harzianum

\begin{tabular}{|l|l|}
\hline Treatment & Inhibition \% \\
\hline F.oxysporum & 44 \\
\hline T.harzianum & 27 \\
\hline
\end{tabular}

Effect of different treatments in the disease severity of the F.oxysporum.

The results showed (Table 3) that no difference between MThPf ,MTh ,MPf ,ThPf, Th and Pf which recorded between 0- $5.56 \%$, when compared with treatments M (Manure) and control which recorded at 13.89 and $22.22 \%$ respectivily. This result agree with (17) The ability of P.fluorscens to protect the plants from the infection with F.oxysporum and reduce the percentage and severity of injury due to the mechanisms used by bacteria inhibition, these mechanisms include the production of antibiotics such as phenazine-1-carboxylicacid, the production of pyoluteorin, $\mathrm{HCN}$, growth-regulating hormones, chitinolytic enzymes, and catalase and producing Siderophores compounds (22) .Bacteria also produce different types of antibiotics such as Pyrrolnitin, 4Diacetylphloroglucinol and Siderophores (23), or through the strong competition for food between the pathogen and the biological resistance factor, which leads to the removal of the pathogen from the root surfaces, which represent the appropriate environment or the effect may be caused by the effectiveness of bacteria in the induction of systemic resistance and stimulate the growth of plants as the bacteria slow the spread of the vaccine Fungal around the roots (24) showed that if time is needed to show the induced resistance in the development of the disease is its effect before the infection.

Table (3) Effect of different treatments on the severity (\%) of infection in the pumpkin plants.

\begin{tabular}{|c|c|}
\hline Treatments & \%Infection \\
\hline MThPf & 0 \\
\hline MTh & 0 \\
\hline MPf & 56.5 \\
\hline Manure & 89.13 \\
\hline ThPf & 0 \\
\hline Th & 78.2 \\
\hline Pf & 78.2 \\
\hline Control & 22.22 \\
\hline LSD 0.05 & 81.5 \\
\hline
\end{tabular}

\section{Effect of different treatments in plant lengths}

The results showed in Table (4) that the mean treatment MThPf increase the length of the plants when recorded $286.49 \mathrm{~cm}$ compared with the control which reached at $70.00 \mathrm{~cm}$. The soil Contaminated with F.oxysporum shows that have an increase in 
plant height rates when reached $200.18 \mathrm{~cm}$ compard with the mean length of plants planted in contaminated soil, which amounted to $162.34 \mathrm{~cm}$. The results of interaction in contaminated soil showed that the treatment MThPf increase the length of the plants, where the height was $253.05 \mathrm{~cm}$ compared to the control in the same soil when reached at $31.72 \mathrm{~cm}$. The reason for increased plant growth due to resistance treatment bacterial biology can be stimulated by plant growth due to its role in increasing nutrient elements (23) or stimulate the growth of the plant and thus strengthen its resistance to pathogens by the production of acid Salicylic acid, which stimulates systemic resistance in the plant as well as the newly recognized ability to stimulate the production of growth hormones Kalawksin and Jabrlin and increase Chlorophyll in leaves $(24 ; ., 25)$ or because of their role in stimulating systemic resistance and resistance to pathogens or within these combined mechanisms (26)This agree with (27). The positive effect of $T$. rhizianum which increased the dry weight of the root and vegetative mass and the plantlength rate to the effect of the bioconcentration factor in inhibiting the activity and inhibition of the pathogen on the one hand, as well as its role in the production of catalysts or regulators for plant growth or by increasing the nutrient elements such as phosphorus, iron and zinc (28).

Table 4 : Effect of different treatments on lengths of pumpkin plants in the soil contaminated or non - contaminated with $F$.oxysporum in the field .

\begin{tabular}{|c|c|c|c|}
\hline \multirow{2}{*}{ Treatments } & \multicolumn{2}{|c|}{ Plant length $(\mathrm{cm})$} & \multirow{2}{*}{ Mean } \\
\cline { 2 - 3 } & $\begin{array}{c}\text { Soil contaminated } \\
\text { with F.oxysporum }\end{array}$ & $\begin{array}{c}\text { Soil with out } \\
\text { F.oxysporum }\end{array}$ & \\
\hline MThPf & 253.65 & 283.93 & 268.49 \\
\hline MTh & 218.72 & 253.14 & 235.93 \\
\hline MPf & 189.63 & 216.64 & 203.14 \\
\hline Manure & 58.89 & 129.34 & 94.12 \\
\hline ThPf & 201.73 & 235.69 & 218.71 \\
\hline Th & 201.97 & 210.39 & 206.18 \\
\hline Pf & 142.72 & 164.04 & 153.52 \\
\hline Control & 31.72 & 108.28 & 70.00 \\
\hline Mean & 162.34 & 200.18 & \\
\hline
\end{tabular}

$\mathrm{LSD}_{0.05}$ of treatment $=36.15$, for soil with or without $F . o=38.34$, for interaction $=23.48$

\section{Effect of different treatments on the soft weight of the vegetative}

The result (Table 5) shows that the mean treatment MThPf increased the weight of the plants when recorded 483.48 gr compared with control which reached at 104.59 gr Soils with out F.oxysporuum showed an increase in the plant weight 304.99 gr compared with average weight of plants cultivated in contaminated soil when reached at 232.04gr. The effect of the interaction between the treatments and their addition to the contaminated soil and uncontaminated showed the treatment of MThPf get an increase in the weight of the soft vegetative plants when recorded 590.12 gr compared with the control that reached at $66.41 \mathrm{gr}$.

This variation in effect may be due to the fact that sterile animal manure is an appropriate environment for fungus growth T.harzianum It is rapidly and densely settled as a result of its containment of nutrient materials and lack of competition for 
other microorganism (29 and 30 ). As a result of the growth and proliferation of T.harzianum profusely in that environment his was clearly reflected in the indicators of growth and productivity of tomato through its secretion of certain substances such as Pyrones (31) or enzymes (32) or secretion of growth regulators (33), this can be explained by the fact that sterile organic substances decompose and release large amounts of dioxide Carbon is thus the formation of a carbonic acid that increases the efficiency of photosynthesis and thus increases total vegetative. T.harzianum has a significant role in nitrogen, phosphorus and sulfur, which has the potential to increase the processing and absorption of nitrogen by the plant and plays an important role in the melting of trace elements $\mathrm{Zn}, \mathrm{Mn}, \mathrm{Cu}$ and $\mathrm{Fe}$ in soil conditions Basal and plant needs in growth and root formation (28).

The researchers confirmed that the ability of bacteria to control the pathogen was not limited to control, but it is believed to have the ability to stimulate the enzymes responsible for the systemic resistance in the plant (34).

Table 5: Effect of different treatments in plant soft vegetative weights (gr) in soil contaminated or non - contaminated with $F$.oxysporum .

\begin{tabular}{|c|c|c|c|}
\hline \multirow{2}{*}{ Treatments } & \multicolumn{2}{|c|}{ Plant soft vegetative wieght (gr) } & \multirow{2}{*}{ Mean } \\
\cline { 2 - 3 } & $\begin{array}{c}\text { Soil contaminated } \\
\text { with F.oxysporum }\end{array}$ & $\begin{array}{c}\text { Soil with out } \\
\text { F.oxysporum }\end{array}$ & \\
\hline MThPf & 376.83 & 590.12 & 483.48 \\
\hline MTh & 315.86 & 359.09 & 337.48 \\
\hline MPf & 217.63 & 311.87 & 291.75 \\
\hline Manure & 136.76 & 175.98 & 156.37 \\
\hline ThPf & 379.22 & 403.36 & .391 .29 \\
\hline Th & 146.56 & 190.16 & 168.36 \\
\hline Pf & 163.05 & 266.62 & 214.84 \\
\hline Control & 66.41 & 142.77 & 59.104 \\
\hline Mean & 232.04 & 304.99 & \\
\hline
\end{tabular}

LSD0.05 of treatment $=76.23$, for soil with or without F.o $=49.51$, For interaction $=120.45$

Determination of some compounds in some treatments using GC-mass technique.

The results appeared as explaned in table (6) that the treatments MThPf, MTh ,MPf ,ThPf ,Th and Pf when analysis with used GCMas revealed transactions in presence of antibiotics and substances Phenol 2,5-bis (1,1-dimethyl), 4-Fluorobenzyl alcohol, Hexadecanoic acid (2) -methyl ester, 1-Pyrrolidine butanoic acid, gammaTocophenol and 9-Octanoic acid (2) -2-hydrox. Some phenolic compounds seemed by Al-daili(2017) in pumpkin when used T.viride as Ascorbic acid 2,6-dihexadecanoate1-(+ 1,3-Propanediol,2-ethyl-2-(hydroxymethyl) , D:B-Friedo-B:A-neogammacer-5en-3-1,(3:beta). 
Table (6)Compounds in plants treated by some factors in contaminated soil.

\begin{tabular}{|c|l|c|}
\hline Treatments & \multicolumn{1}{|c|}{ Compounds } & Molecular weight \\
\hline MThPf & Elaidic acid , Phenol,2,5-bis(1,1-dimethyl ethyl) & 55 \\
& isopropleste & 84 \\
& Silane diethylpentadecyloxy-13-phenol & 33 \\
\hline \multirow{3}{*}{ MTh } & 4-Fluorobenzyl alcohol Methyl & 46 \\
& Methyl Tetradecanote & 97 \\
& 2-pentadecaneno-6-10-14-trimethyl & 49 \\
& Hexadecanoic acid - methyl ester & 98 \\
\hline \multirow{3}{*}{ MPf } & Cyclohexadecane,1,2-diethyl & 95 \\
& 9-Octdecenoic acid (2)-hydrox & 99 \\
& Gamma-Tocopherol & 94 \\
\hline ThPf & Natolensine-3,5-dintrobenzoate & 92 \\
& Phenol-2,5-bis(1,1-dimethyl ethyl) & 70 \\
\hline Th & Trichloromethan & 97 \\
& 9-Octadecanonic acid & 96 \\
& 2)-methyl ester & 99 \\
& Hexadecanoic acid - methyl ester & 95 \\
\hline \multirow{2}{*}{ Pf } & Cyclohexadecane ,1,2-diethyl & 37 \\
& 1-pyrrolidne butanoic acid & 62 \\
\hline
\end{tabular}

\section{CONFLICT OF INTERESTS.}

There are non-conflicts of interest.

\section{References}

1- Matloob, A.N.; Mohamed, E.S and Karim Saleh Abdul. (1989). Vegetable production ,Second revised edition.

2- Adedayo OR, Farombi AG, Oyekanmi AM (2013). Proximate, mineral and antinutrient evaluation of pumpkin (Cucurbita pepo). J Applied Chem 4: 25-28.

3- Carvalho LMJ, Smiderle LAZM, Carvalho JLV, Cardoso FSN, Koblitz MGB (2014). Assessment of carotenoids in pumpkins after different home cooking conditions. Food Sci Technol 34: Campinas April/June

4- Owen, J.H. (1959). Fusarium Wilt of Cucumber. Pathology. University of Florida

5- AL-Homeidan, H.H. and Saloom, A.N. (2007). The Biocontrol of Fusarium oxysporum by Pseudomonas fluorescens on Cucurbita pepo plant. Saudi Journal of Biological Sciences. 14 (2) 169-176.

6- Al - Waily, D.S.A (2004). Astudy of tomato seedling damping-off disease and their Integrated Control in the fields of Zubair and Safwan in Basrah.PhD thesis.Faculty Sciences, Basrah.Uni.

7- Jayamathi, T.; Komalavalli, N. and Paudiyarajan,V. (2012). GC-MS analysis of leaf ethanolic extracts of wrightia tinctoria - a high medicinal value plant. Asian J. Plant Science and Research, 2(6) : $688-691$.

8- Booth, C. (1971). The Genus Fusarium . Common Wealth. Institute, Kew, Surrey, England. $237 \mathrm{pp}$

9- Pitt, J. I. and Hocking, A.D. (1997). Fungi and food spoilage. Blackie Acadimic and Professional,University Press, Second Edition. 592 pp.

10- Agrios, G.N.(2007). Plant pathology. 4th Ed.. Academic press New York. U.S.A. 606pp.

11- Al- Shukri, Mehdi Medid (1991) .The basics of fungi and their plant diseases, Baghdad Uni., 412 pp. 
12- Al-Issawi, T.A.W. (2006). Isolation and diagnosis of some fungus associated with the death of seedling and rotting the roots of water melon on growth and resistance by biochemical and chemical. Master Thesis, Technical College/ Musayyib, 66 pp.

13- Hassan, A. K. (2005). Evaluation of the Effectiveness of Some Factors of Induction and Pesticides in Protecting cucumber from Pythium aphanidermatum, Master Thesis, Faculty of Agriculture, University of Baghdad.

14- Al - Haidari, Ali Jassim. (2007). Isolation and diagnosis of fungus causing the death of papaya plants and their resistance to different techniques of fungi Trichoderma harzianum 14-Rifai. Master Thesis, Faculty of Agriculture, University of Kufa.

15- Abdel Moneim, Osama Abdel Karim (2007). Effect of animal fertilizers on the numerical density of fungus in desert soils and its importance on growth indicators and the yield of tomato plant. Master Thesis. Faculty of Agriculture - University of Kufa.

16- Anderson, T.H.; Gams, W. and Domsch, K.H.(2003). Compendium of soil fungi. Academic Press, London, 894 . pp.

17- Abdul Rida, Amal Saleh (2005). The efficiency of some Pseudomonas fluorescens isolates is evaluated Protection of Tomato Plants from Fusarium oxysporum Schl.f.sp. lycopersici, With a study of the root of the host, Master of the Faculty of Education, University of Basra, 84 pp.

18- Furuya. N., Kushima. Y., Tsuchiya. K., Matsuyama. N., and Wakimoto. S.(1991). Protection of tomato seedings by Pre-treatment with Pseudomonas 13glumae from Infection with Pseudomonas solanacearum and Its Mechanisms. Ann. Phytopath. Soc. Japan. 57:363-370.

19- Thomashow L. S. and Weller. D. M. (1988). Role of Aphenazine antibiotic from Psendomonas fluorescens in biological control of Geaumannomyces var. tritici170 (8): 3499-3508.

20- Banasco, P., Fuente, L De La, Gaultieri, G., Noya, F. and Arias, A. (1998). Fluorescent Pseudomonas spp. as biocontrol agents against forage legume root pathogenic fungi. Soil Biol. Biochem., , 10, 1317-1323.

21- Ziedan, E.H., Saad M.(M.) and S. Farrag (Eman), (2005). Biological control of grapevine root rot antagonistic. Journal of Biology. 3:79-87.

22- Maurhofer, M., Keel, C.; Haas, D. and Defago, G. (1994). Pylouteorin production by Pseudomonas fluorescens strain $\mathrm{CHAO}$ is involved in the suppression of Pythium damping- off of cress but not of cucumber. European Journal of Plant Pathology. 100: 221- 232 .

23- Bakker, P.A.H.M.; L.X, Ran; C.M.J. Pieter s and Van Loon L.C., (2003). Understanding the involvement of rhizosphere bacteria mediated induction of systemic resistance in biocontrol of plant diseases . Can. Journal Plant Pathology. 25,5-9.

24- McCullagh, M.; Utkhede, R.; Menzies , J.G.; Punja, Z.K. and Paulitz, T.C. (1996). Evaluation of plant growth promoting rhizobactria for biological control of Pythium root rot of cucumbers grown in rock wool and effects on yield . European Journal of Plant Pathol. 102 : 747-755.

25- Leeman , M.; Denouden , F.M.; Vanpelt , J.A.; Dirkx , F.P.M. and Steijl , H. (1996). Iron availability affects induction of Systemic resistance to fusarium wilt of radish by Pseudomonas fluorescens. Phytopathol. $86: 149-155$

26- Shehata, S.M., Saeed, M.A. and ABou-El-Nour, M.S.( 2000). Physiological response of cotton plant to the foliar spray with salicylic acid. Annals Agric. Sci., Ain Shams Univ., Cairo, 45(1): 1-18 
27- Kloepper, J.W.; Rodringnez - Kapana , R.; Zehnder , G.W.; Murphy, J.F.; Sikora , E. and Frenadez, C. (1999). Plant root-bacterial interactions inbiological control of soil borne disease and potential extension to systemic and foliar disease. Australian Plant Pathology. 28

28- Jbara,I.M. (2002). The effect of solar pasteurization on the survival of the biological resistance resistors (Trichoderma harzianum) and the persistence of lilacinus Paecilomyce in combating some root diseases in protected agriculture. Master Thesis - Faculty of Agric. Baghdad.Uni.

29- Altomare, C.;W.A. Norvell.;T. Bjorjman. And G.E. Harman. (1999). Solubilization of phosphate and micronutrients by the plant growth promoting and biocontrol Trichoderma harzianum. Rifai 1295-22. Appl. Eniveron. Microbiol 65: 29262933.

30- Diwan, M.M.; Sahib,V.I. and Jawad S.M., (2007). The effect of micronutrients in enhancing the ability of mushrooms Trichodaema harzianum to improve the growth of plants Albamea and the establishment of wilt Rhizoctonia. Accepted for publication in Karbala scientific journal.

31- Al-Obeidi, O.K. (2005). Use of Trichoderma harzianum Rifai in the control of soil fungi Rhizctonia solani and Fusarium solani Nurses. Master Thesis. College of Technology / Musayyib.

32- Ghisalberti, E.L.; Narbey, M.J.; Dewan, M.M. and Sivasithmparam, K. (1990). Viability among strains of Trichoderma harzianum in their ability and reduce takeall to produce pyrones. Plant \& Soil., 121:291.

33- Aziz, A.Y., Foster, H.A. and Fairhurst, C.P. (1993).Invitro interactions between Trichoderma spp and Ophiostomaulmiand their cations for the biological control of Dutch elm disease and other fungal disease. Arb-biocultural Journal. 17: 2. 145157.

35- Windham, M.T.; Elad, Y. and Baker, R. (1986). A mechanism for increased growth induced by Trichoderma spp. Phytopathology. 76:518-521.

36- Chen, C., R. Belanger, N. Benhamou and T.C. Paulitz. (2000). Defense enzymes induced in cucumber roots by treatment with plant growth promoting rhizobacteria (PGPR) and Pythium aphanidermatum. Physiological and molecular plant pathology .56:13-23. 